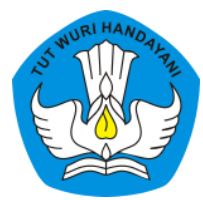

Page: 821-842

\title{
PENINGKATAN KEMAMPUAN MEMBACA ORDINAL NUMBER DENGAN MENGGUNAKAN BOLA-BOLA HYPNOTIST DALAM 5M
}

\section{Zaimatun}

Sekolah Menengah Pertama Negeri 1, Sarang, Indonesia

Contributor Email: zaimatun.alfaruq@gmail.com

\begin{abstract}
The aims of using Hypnotist balls in $5 M$ is to increase the students' ordinal number reading competency and students' activeness in the learning process. Hypnotist balls is a hypnoteaching communication medium implementation. While, 5M is a scientific approach that concists of observing, questioning, data collecting, associating, and communicating. This research uses classroom Action Research method which is designed by Stephen Kemmis dan Robyn Mc. Taggart that is acted in two cycles. Each cycle concists of planning, acting, observing, and reflecting. The result of the research shows that by using hypnotist balls, the students' ordinal numbers reading increases 38,35\%. The students' learning activeness also increases 17.24\%. Hypnotist balls in 5M helps the students' learning process very much.
\end{abstract}

Keywords: Reading Ordinal Number; Hypnotist Balls; 5M. 


\begin{abstract}
Abstrak
Tujuan penggunaan bola-bola hypnotist dalam 5M adalah untuk meningkatkan kemampuan membaca ordinal number dan keaktifan peserta didik dalam pembelajaran. Bolabola hypnotist adalah media komunikasi dalam penerapan hypnoteaching. Sedangkan, 5M adalah pendekatan saintifik, yang melipuiti mengamati, menanya, mengumpulkan data, mengasosiasi, dan mengomunikasi. Metode penelitian ini adalah PTK model Stephen Kemmis dan Robyn Mc. Taggart yang meliputi dua siklus. Setiap siklus terdiri atas perencanaan, tindakan, observasi, dan refleksi. Hasil penelitian menunjukkan dengan bola-bola hypnotist dalam 5M kemampuan membaca ordinal number peserta didik mengalami peningkatan sebesar 38,35\%. Keaktifan belajar peserta didik juga meningkat 17,24\%. Bola-bola hypnotist dalam 5M sangat membantu peserta didik dalam pembelajaran.
\end{abstract}

Kata Kunci: Membaca Ordinal Number; Bola-bola Hypnotist; 5M.

\title{
A. Pendahuluan
}

Materi ordinal number mata pelajaran bahasa Inggris dipelajari di kelas 7, semester ganjil. Sesuai dengan Permendikbud no. 37 tahun 2018, materi ini ada pada KD. 3.2, yaitu: Mengidentifikasi fungsi sosial, struktur teks, dan unsur kebahasaan teks interaksi transaksional lisan dan tulis yang melibatkan tindakan memberi dan meminta informasi terkait nama hari, bulan, nama waktu dalam hari, waktu dalam bentuk angka, tanggal, dan tahun, sesuai dengan konteks penggunaannya. Dalam KD 3.2 ini pendidik diharapkan memerhatikan kosa kata terkait angka kardinal dan ordinal (Kemdikbud RI, 2018). Yang dimaksud ordinal number dalam KD tersebut adalah "angka urutan", yang sangat erat kaitanya dengan hari, bulan, waktu, tanggal, dan tahun.

Sebenarnya, peserta didik kelas VIIA telah mempelajari materi ordinal number ini. Hasil angket menunjukkan 100\% dari 32 peserta didik kelas VIIA di Sekolah Menengah Pertama Negeri 1 Sarang, kabupaten Rembang, Jawa Tengah, yang berasal dari delapan Sekolah Dasar di Kecamatan Sarang, telah belajar ordinal number. Berdasarkan data di atas, seharusnya peserta didik telah memiliki intake yang cukup untuk menguasai keterampilan membaca ordinal number. Idealnya pula, peserta didik tidak 
mengalami kesulitan dalam mengerjakan soa-soal setelah melakukan pembelajaran. Misalnya dalam mengerjakan soal-soal ulangan harian.

Kenyataanya, peserta didik kelas 7A menemui banyak masalah dalam menguasai keterampilan membaca ordinal number. Pada saat pembelajaran, sebetulnya mereka dapat mengikuti dan menguasai dengan cepat. Bahkan, beberapa terkesan menganggap enteng materi tersebut. Akan tetapi, beberapa minggu kemudian, saat diadakan ulangan harian, mereka melupakan apa yang telah mereka kuasai. Terlihat dari cara menjawab mereka yang masih terpengaruh bahasa Indonesia, bahasa ibu mereka. Nikelas dalam Sri wahyuni mengatakan bahwa penyebab utama dari masalah dan kesalahan dalam bahasa asing adalah gangguan yang berasal dari bahasa asli para pelajar (Sri Wahyuni, 2015). Ini yang menyebabkan nilai rata-rata kelas hanya 45,40 dari kriteria ketuntasan minimal 75. Dari 32 peserta didik, hanya sebelas peserta didik yang tuntas.

Ada dua faktor penyebab permasalahan ini, yaitu dari peserta didik dan dari pendidik, dalam hal ini penulis. Faktor pertama, peserta didik menganggap enteng materi yang mereka pelajari. Ini membuat mereka tidak maksimal dalam melaksanakan pembelajaran. Akibatnya, mereka tidak maksimal pula dalam menyerap materi. Dampaknya, mereka mudah melupakan apa yang telah mereka pelajari. Faktor kedua, cara penyampaian serta strategi pembelajaran yang digunakan pendidik kurang tepat. Pendidik menganggap tidak perlu media dan strategi khusus untuk materi ini, karena materi ini sebelumnya telah peserta didik pelajari. Pendidik hanya mengajar secara convensional. Oleh sebab itu, pendidik perlu mencari solusi agar peserta didik tetap antusias selama pembelajaran, tapi tidak melupakan apa yang telah mereka pelajari. Penggunaan media bola-bola hypnotist dalam 5M adalah salah satu solusinya.

Tujuan penelitian ini adalah: pertama, untuk mengetahui bagaimana peningkatan kemampuan membaca ordinal number dengan menggunakan Bola-bola hypnotist dalam 5M. Beberapa teori membaca diantaranya menyatakan bahwa tujuan khusus pembelajaran bahasa Inggris mencakup tiga hal yaitu: (1) tujuan khusus pembelajaran kebahasaan, (2) meningkatkan kemampuan pemahaman, dan (3) penggunaan bahasa. Selanjutnya dijelaskan 
bahwa pembelajaran pemahaman bertugas mengembangkan kemampuan untuk menyerap gagasan, pendapat, pengalaman, serta pesan yang dilisankan atau ditulis (Nurli et al., 2019). Sementara Grabe dalam Heri Susanto menyatakan "Reading is something many of people use it for purposes. People just read with or without on purposes" artinya membaca adalah sesuatu yang kebanyakan orang menggunakanya dengan beberapa alasan. Banyak orang membaca dengan atau tanpa tujuan (Susanto, 2020). Sedangkan Mortimer J. Adler dan Charles Van Doren dalam Ida Farida Sachmadi, Lestari Manggong, dan Lia Maulia Indrayani, sebagaimana dikutip Rohman, dalam bukunya yang berjudul How to Read a Book, menyatakan bahwa "Reading is tools", artinya membaca adalah alat (Sachmadi et al., 2018). Anderson (1985), Rubin (1982), dan Nuttal (1992) seperti yang dikutip Rahmawati Fitriana menyatakan bahwa membaca selalu memiliki tujuan yang berbeda, namun tujuan akhirnya adalah akan terjadi komunikasi antara pembaca, teks dan penulis, sehingga makna teks yang dibawa oleh penulis dapat diterima oleh pembaca dengan baik (Fitriana, 2020). Dari beberapa teori tersebut dapat disimpulkan bahwa agar dapat memahami teks yang dibaca, seseorang harus mempunyai tujuan dalam membaca.

Sedangkan teori tenteng ordinal number berkaitan erat dengan cardinal number. Sumardi, Lutfi Nur, dan Hilma Halimatus Sa' diyyah menyatakan bahwa angka kuantitas (cardinal number) menjelaskan tentang "berapa banyak". Misalnya, angka dua (2) itu berarti dua buah apel, dua ekor ayam atau dua orang teman. Sedangkan angka urutan (ordinal number) menjelaskan tentang nomor urutan yang dimulai dengan angka 1 dan dilanjutkan dengan angka 2, 3, 4, 5, 6, 7, ...dst. Angka urutan (ordinal number) memiliki pengaruh besar dalam menghitung angka kuantitas (cardinal number). Ketika seseorang dapat menalar urutan angka dengan baik dan benar maka seseorang tersebut dapat menentukan jumlah subjek dalam satu koleksi dengan baik dan benar pula(Nur, 2017). Dalam penelitian ini penulis hanya fokus pada ordinal number.

Dihubungkan dengan tujuan penelitian ini, peningkatan kemampuan membaca ordinal number dapat dijelaskan sebagai peningkatan kemampuan untuk menyerap gagasan, pendapat, pengalaman, serta pesan nomor urutan 
yang tertulis. Agar dalam menyerap gagasan, pendapat, pengalaman, serta pesan tertulis bisa maksimal, kegiatan membaca harus disertai tujuan. Tujuan ini merupakan alat untuk memahami pesan penulis dari teks yang dibaca. Kemampuan pemahaman yang baik akan menjadi alat pula dalam memahami teks-teks yang lain. Sebagai contoh, kemampuan membaca ordinal number (angka urutan) dapat menjadi alat untuk memahami cardinal number (angka kuantitas).

Bola-bola hypnotist adalah adalah media pembelajaran yang penulis ciptakan. Media pembelajaran ini berfungsi sebagai media komunikasi dalam penerapan hypnoteaching. Media ini terdiri dari beberapa bola dengan warna yang mencolok. Setiap warna mewakili satu instruksi/ pertanyaan yang harus dikerjakan/dijawab peserta didik. Media ini berbahan karet berdiameter $10 \mathrm{~cm}$, dengan maksud tidak terlalu besar bila berada dalam genggaman tangan kanan orang dewasa. Dengan menggunakan media ini, pendidik tidak perlu meberikan instruksi secara verbal kepada peserta didik selama proses pembelajaran, tapi cukup dengan menunjukkan bola-bola hypnotist saja.

Media pembelajaran, termasuk juga bola-bola hypnotist mempunyai peranan yang sangat penting dalam mencapai tujuan pembelajaran. Seberapa penting peran sebuah media pembelajaran, dapat dilihat dari beberapa hasil penelitian berikut ini. Pertama adalah penelitian Pipit Puji Astutik yang berhasil meningkatkan kemampuan literasi dan berpikir kreatif peserta didik dengan menggunakan media sampah (Astutik, 2018). Kedua, penggunaan lingkar tiga warna yang mampu meningkatkan motivasi dan hasil belajar peserta didik dalam pembelajaran comparison of degree (Hidayat, 2020). Ketiga, penggunaan permainan ular tangga berangkas yang mampu meningkatkan kemampuan berbicara bahasa inggris (Maiti \& Bidinger, 1981). Keempat, penggunaan grafik nada dengan remot control untuk meningkatkan keterampilan membaca notasi angka (Handayani et al., 2018). Kelima, media break and put yang dapat meningkatkan hasil belajar teks report (Jaya et al., 2019). Seperti halnya penelitian-penelitian sebelumnya, penulis menggunakan media bola-bola hypnotist ini untuk meningkatkan kemampuan membaca ordinal number. 
Bola-bola hypnotist ini erat kaitanya dengan kesuksesan pendidik selama pembelajaran. Ridwan Sank, seorang hypnovator mengatakan ada tiga pintu yang bisa mengantar seseorang sukses berbicara di depan umum, termasuk pendidik di depan kelas. Yang pertama adalah pintu visual (apa yang dilihat peserta didik). Persentase pintu ini terhadap kesuksesan seseorang tadi adalah 55\%. Kedua pintu verbal (pesan yang ingin disampaikan), persentasenya $38 \%$. Yang ketiga pintu voice (apa yang didengar oleh peserta didik), dengan persentase 7\% (Vinet \& Zhedanov, 2011). Dapat dilihat, aspek visual mempunyai pengaruh paling besar dalam pembelajaran. Oleh sebab itu, penulis menciptakan bola-bola hypnotist. Ini dapat dikategorikan aspek visual dari pintu tiga tadi. Aspek visual ini dapat didukung oleh penampilan pendidik. Sebagaimana dikatakan Muhammad Nur, bahwa beberapa hal yang harus diperhatikan dalam melakukan hypnoteaching adalah penampilan guru, teknik komunikasi, dan sugesti yang positif (Noer, 2010).

Hypnoteaching adalah penerapan teknik komunikasi untuk membantu meningkatkan efektifitas pengajaran bagi pendidik, baik di dalam maupun di luar kelas (Vinet \& Zhedanov, 2011). Teknik hypnoteaching ini mengupayakan bekerjanya pikiran bawah sadar peserta didik secara optimal selama pembelajaran. Kondisi ini akan membuat peserta didik lebih mudah dan merasa nyaman dalam menerima instruksi pendidik. Menurut Wandi R. dalam Muhammad Anwar, berdasarkan cara kerjanya, otak manusia dapat dibagi menjadi otak kiri dan otak kanan. Otak kiri disebut pikiran sadar (conscious), hanya memegang peranan 12\% terhadap kesuksesan kita. Sedangkan otak kanan disebut pikiran bawah sadar (subsconscious), memegang peranan $88 \%$ (Pane et al., 2018). Pendapat senada dengan sedikit selisih persentase mengatakan bahwa pengaruh dan peran pikiran sadar terhadap diri seseorang sebanyak $15 \%$, sedangkan pikiran bawah sadar mencapai 85\% (Dj, 2015). Dengan kata lain, 85\% sampai 88\% aspek kehidupan peserta didik dipengaruhi oleh pikiran bawah sadar. Pikiran bawah sadar akan merekam kuat informasi dalam memori dan akan banyak memengaruhi sebgian besar aspek kehidupan peserta didik. 
Menurut ilmu hypnoteaching, pikiran manusia, termasuk peserta didik terdiri dari tiga lapisan: pikiran sadar, critical factor/critical area, dan pikiran bawah sadar. Pikiran sadar adalah proses mental atau pikiran dimana peserta didik sepenuhnya berada pada kondisi sadar. Pikiran sadar berfungsi menganalisis segala informasi yang masuk, membandingkan dengan data yang telah tersimpan dalam memori, kemudian memutuskan informasi baru yang akan disimpan atau dibuang dalam memori. (Hana Pertiwi, S.Pd. 2014). Agar pikiran bawah sadar peserta didik bisa bekerja dengan optimal, pendidik harus bisa menembus critical area yang berfungsi sebagai pelindung pikiran bawah sadar dari pengaruh buruk pikiran sadar. Bola-bola hypnotist ini berfungsi untuk menembus critical area dan mengaktifkan pikiran bawah sadar peserta didik selama pembelajaran.

Dalam penelitian ini penggunaan media bola-bola hypnotist dikombinasikan dengan pendekatan 5M. Pendekatan $5 \mathrm{M}$ yang penulis maksud adalah pendekatan saintifik yang melipuiti Mengamati, Menanya, Mengumpulkan data, Mengasosiasi, dan Mengomunikasi (Kemendikbud, 2014). Nanik Jusnita dan Anwar Ismail mengemukakan pendekatan saintifik ini sedikit berbeda, yaitu meliputi: Mengamati/Observing, Menanya/ Questioning, Menalar/ Associating, Mencoba/ Experimenting, dan mengomunikasikan/ Networking (Jusnita \& Ismail, 2018). Sementara itu, Tita Tanjung sari dan Rival Hanip berpendapat scientific thining sangat sesuai dengan teori Bruner yang menyatakan bahwa belajar terbaik adalah belajar penemuan (Sari \& Hanip, 2018). Sedangkan inti dari pendekatan saintifik ini dapat dilihat dari Roy Killen dalam Udin Saubas, bahwa pendekatan saintifik ini termasuk student-centred approaches atau pendekatan yang berpusat pada peserta didik (Saubas, 2016). Menyimpulkan dari beberapa pendapat tentang pendekatan saintifik, penulis berharap pendekatan $5 \mathrm{M}$ ini akan lebih mengoptimalkan penggunaan bola-bola hypnotist.

Tujuan kedua penelitian ini adalah untuk mengetahui peningkatan keaktifan peserta didik selama pembelajaran membaca ordinal number dengan menggunakan Bola-bola hypnotist dalam 5M. Meningkatnya kemampuan peserta didik akan berpengaruh pada peningkatan kepercayaan diri. Dengan kepercayaan diri yang tinggi, peserta didik akan lebih aktif 
selama pembelajaran. Bola-bola hypnotist dalam $5 M$ akan membantu peserta didik mengoptimalkan pikiran bawah sadar mereka, sehingga mereka dapat lebih terfokus tapi tetap rileks selama pembelajaran. Hasil belajar akan terekam kuat dalam memori, sehingga tidak mudah terlupakan. Mereka akan dengan mudah mengingat kembali hasil pembelajaran untuk menyelesaikan soa-soal saat ulangan harian.

\section{B. Metode}

Penelitian ini menggunakan metode Penelitian Tindakan Kelas, mengadopsi model Stephen Kemmis dan Robyn Mc Taggart. Model penelitian tindakan kelas ini meliputi dua siklus. Setiap siklus terdiri atas perencanaan, tindakan, observasi, dan refleksi. Penelitian ini memerlukan kolaborasi yang baik antara peneliti dan rekan pendidik sesama bidang mata pelajaran sebagai kolaboran. Bersama kolaboran peneliti melakukan diskusi tentang perencanaan tindakan dan perencanaan perbaikan setelah tindakan refleksi. Kolaboran juga mempunyai andil besar dalam proses tindakan, yaitu melakukan observasi selama tindakan berlangsung. Desain penelitian tersebut dapat dilihat pada bagan berikut.

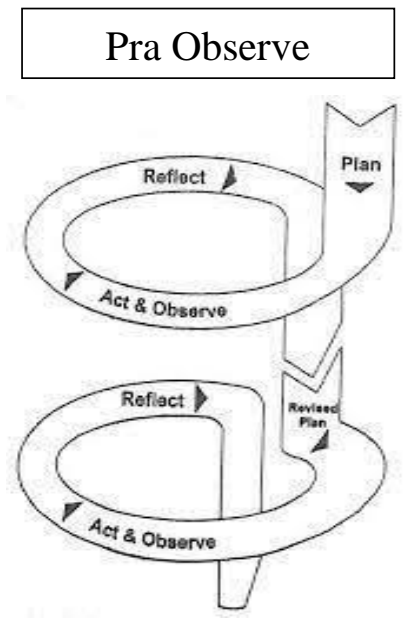

Penelitian ini dilaksanakan pada semester ganjil tahun pelajaran 2019/2020. Variable penelitian tindakan kelas ini adalah kemampuan membaca ordinal number menggunakan bola-bola hypnotist dalam 5M. Sedangkan subjek penelitian ini adalah peserta didk kelas VIIA Sekolah 
Menengah Pertama Negeri I Sarang, yang berjumlah 32 peserta didik terdiri dari 11 peserta didik perempuan dan 21 peserta didik laki-laki.

Penelitian ini dilaksanakan dalam dua siklus. Masing-masing siklus terdiri dari dua pertemuan. Setiap pertemuan empat puluh menit. Sebelum melaksanakan siklus 1, penulis melakukan tindakan pra siklus yaitu dengan memberikan tes pada subjek penelitian untuk mengetahui kemampuan membaca ordinal number mereka. Dilanjutkan dengan siklus 1 yang terdiri dari perencanaan, tindakan, observasi dan refleksi.

Refleksi siklus 1 penulis gunakan untuk melakukan perbaikan perencanaan untuk siklus 2. Selanjutnya pelaksanaan siklus 2 yang terdiri dari perencanaan, tindakan, observasi dan refleksi. Hasil refleksi siklus 2 diharapkan telah menunjukkan bahwa keterampilan membaca ordinal number peserta didik telah meningkat secara signifikan. Keaktifan peserta didik selama pembelajaran juga meningkat.

Instrumen Penelitian ini adalah instrument test dan nontest. Instrument test berupa soal-soal yang berhubungan dengan keterampilan membaca ordinal number. Sedangkan instrument non-test berbentuk lembar angket, lembar observasi, sosiometri, dan dokumentasi. Pengambilan data menggunakan teknik test dan non-test (angket, observasi, sosiometri, dokumentasi) kemudian dianalisis secara kuantitatif dan kualitatif. Teknis test dilaksanakan dengan cara memberikan soal-soal yang berhubungan dengan ordinal number. Ini dilaksanakan pada pra siklus, siklus 1, maupun siklus 2. Tujuanya untuk mengetahui kemampuan membaca ordinal number sebelum dan sesudah penggunaan bola-bola hypnotist dalam 5M. Teknik non-test berupa angket diberikan untuk mengetahui apakah peserta didik telah mempelajari ordinal number saat di Sekolah Dasar. Sedangkan teknik observasi bertujuan untuk mengetahui keatifan peserta didik selama pembelajara. Sosiometri bertujuan untuk mengetahui keaktifan peserta didik dalam kelompok kerjanya. Sedangkan teknik dokumentasi bertujuan untuk mendokumentasikan kegiatan-kegiatan selama penelitian.

Indikator keberhasian penelitian ini ditentukan oleh tiga hal. Yang pertama, peningkatan kemampuan membaca ordinal number. Penelitian ini dikatakan berhasil jika pada akhir penelitian, persentase nilai kelas mencapai 
minimal 75\% (kategori C). Kedua, peningkatan persentase ketuntasan belajar peserta didik. Penelitian ini dikatakan berhasil jika pada akhir penelitian persentase ketuntasan belajar peserta didik mencapai minimal 75\% (kategori C). Yang terakhir adalah peningkatan keaktifan peserta didik dalam pembelajaran. Jika keaktifan peserta didik pada akhir penelitian mencapai minimal 75\%(kategori C), penelitian ini dikatakan berhasil. Indikator ini didasarkan pada rentang nilai berdasarkan kriteria ketuntasan minimal.

\section{Hasil dan Pembahasan}

\section{Hasil}

Hasil penelitian dapat dilihat dari tabel 1, table 2, dan diagram 1 berikut ini. Tabel 1 menunjukkan peningkatan kemampuan membaca ordinal number menggunakan bola-bola hypnotist dalam 5M. Diagram 1 menunjukkan peningkatan ketuntasan belajar peserta didik. Sedangkan tabel 2 menunjukkan peningkatan keaktifan peserta didik dalam pembelajaran. Peningkatan ini terjadi karena penggunaan media bola-bola hypnotist dalam $5 M$.

Tabel 1. Peningkatan Kemampuan Membaca Ordinal Number Menggunakan Bola-bola Hypnotist dalam 5M

\begin{tabular}{|c|c|c|c|c|c|c|c|}
\hline \multirow[b]{2}{*}{ No. } & \multirow{2}{*}{$\begin{array}{l}\text { Predikat, Kategori dan } \\
\text { Rentang Nilai }\end{array}$} & \multicolumn{2}{|c|}{ Pra Siklus } & \multicolumn{2}{|c|}{ Siklus 1} & \multicolumn{2}{|c|}{ Siklus 2} \\
\hline & & $\begin{array}{c}\text { Bobot } \\
\text { Skor }\end{array}$ & (\%) & $\begin{array}{l}\text { Bobot } \\
\text { Skor }\end{array}$ & $(\%)$ & $\begin{array}{c}\text { Bobot } \\
\text { Skor }\end{array}$ & (\%) \\
\hline 1. & A, Sangat Baik, $>92-100$ & - & - & 480 & $18,75 \%$ & 276 & $10,30 \%$ \\
\hline 2. & B, Baik, > $>83-87$ & 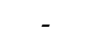 & - & 840 & $32,81 \%$ & 1484 & $55,37 \%$ \\
\hline 3. & C, Cukup, $>75-73$ & 80 & $5,5 \%$ & 936 & $36,56 \%$ & 708 & $26,42 \%$ \\
\hline 4. & D, Kurang, $<75$ & 1373 & $94,5 \%$ & 304 & $11,87 \%$ & 212 & $7,91 \%$ \\
\hline \multicolumn{2}{|c|}{ Jumlah } & 1453 & $100 \%$ & 2560 & $100 \%$ & 2680 & $100 \%$ \\
\hline \multicolumn{2}{|c|}{ Rata-rata } & \multicolumn{2}{|c|}{45,40} & \multicolumn{2}{|c|}{80,00} & \multicolumn{2}{|c|}{83,75} \\
\hline \multicolumn{2}{|c|}{ Persentase } & \multicolumn{2}{|c|}{$45,40 \%$} & \multicolumn{2}{|c|}{$80,00 \%$} & \multicolumn{2}{|c|}{$83,75 \%$} \\
\hline \multicolumn{2}{|c|}{ Peningkatan(\%) } & & & \multicolumn{2}{|c|}{$34,60 \%$} & \multicolumn{2}{|c|}{$3,75 \%$} \\
\hline \multicolumn{2}{|c|}{ Peningkatan pada Akhir Penelitian } & & & \multicolumn{4}{|c|}{$38,35 \%$} \\
\hline
\end{tabular}

Hasil test menunjukkan bahwa terjadi peningkatan kemampuan membaca ordinal number pada peserta didik kelas VIIA Sekolah Menengah Pertama Negeri 1 Sarang setelah penggunaan bola-bola hypnotist dalam 5M. Pada pra siklus, rata-rata nilai peserta didik hanya 45,40. Pada siklus 1 mengalami peningkatan drastis, yaitu 80,00. Kemudian pada siklus 2 rata-rata perolehan nilai meningkat lagi menjadi 83,75. Dapat dikatakan 
bahwa presentase nilai kelas meningkat dari pra sikus $45,40 \%$ menjadi $80,00 \%$ pada siklus 1,dan meningkat lagi menjadi $83,75 \%$ pada siklus 2 . Artinya, pada pada akhir penelitian persentase nilai kelas mencapai $83,75 \%$ dengan predikat baik. Peningkatanya sebesar $34,60 \%$ dari pra siklus ke siklus 1, dan 3,75\% dari siklus 1 ke sikus 2 . Artinya dibandingkan dengan hasil test pada pra siklus, maka ada peningkatan sebesar 38,35\% pada akhir penelitian.

Sebutan predikat A (sangat baik), B (baik), C (cukup), dan D (kurang) didasarkan pada rentang nilai yang telah ditentukan pada awal tahun pelajaran. Ini dilakukan dalam musyawarah guru mata pelajaran tingkat sekolah. Penentuan rentang nilai adalah dengan memulai predikat $\mathrm{C}$ dengan kriteria ketuntasan minimal, yaitu 75. Caranya adalah nilai maksimal dikurangi kriteria ketuntasan minimal, kemudian dibagi 3 (100-75:3), hasilnya 8,3. Maka, panjang interval untuk setiap predikat adalah 8 atau 9. Sehingga diperoleh rentang nilai sebagai berikut. $<75$ adalah D (kurang), $\geq 75$ - 83 adalah C (cukup), >83 - 92 adalah B (baik), dan >92 - 100 adalah A (sangat baik) (Kemdikbud RI, 2017).

Diagram 1. Ketuntasan Belajar Peserta didik

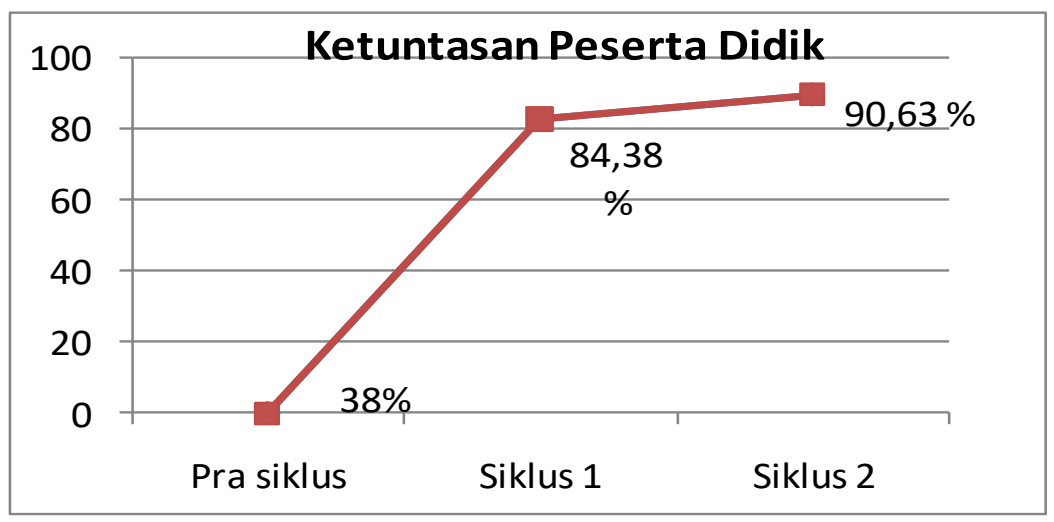

Diagram 1 menunjukkan persentase peningkatan ketuntasan belajar peserta didik. Dengan menggunanakan bola-bola hypnotist dalam 5M pada pembelajaran membaca ordinal number, ketuntasan belajar kelas VIIA Sekolah Menengah Pertama Negeri 1 Sarang juga meningkat. Terbukti pada pra siklus, ketuntasan belajar hanya mencapai 38\%. Kemudian pada siklus 1 
meningkat menjadi 84,38\%, dan pada siklus 2 meningkat lagi menjadi 90,63\%. Artinya, dari 32 peserta didik, pada pra siklus hanya ada 11 peserta didik yang tuntas. Kemudian pada siklus 1 meningkat menjadi 27 peserta didik, dan pada siklus 2 meningkat lagi menjadi 29 peserta didik.

Tabel 2. Keaktifan Belajar Peserta Didik

\begin{tabular}{|c|c|c|c|c|c|}
\hline \multirow{2}{*}{ No. } & \multirow{2}{*}{ Indikator Perilaku Positif } & \multicolumn{2}{|c|}{ Siklus 1} & \multicolumn{2}{|c|}{ Siklus 2} \\
\hline & & $\mathbf{F}$ & $(\%)$ & $\mathbf{F}$ & $(\%)$ \\
\hline 1. & $\begin{array}{l}\text { Peserta didik memperhatikan dan merespon dengan antusias } \\
\text { (bertanya,menanggapi, dan mencatat) }\end{array}$ & 32 & 100 & 32 & 86,20 \\
\hline 2. & Peserta didik berpartisipasiaktif dalam berkelompok & 31 & 79,31 & 30 & 75,86 \\
\hline 3. & $\begin{array}{l}\text { Peserta didik merasa senang belajar teks ordinal number } \\
\text { menggunakan media realia }\end{array}$ & 30 & 100 & 32 & 100 \\
\hline 4. & $\begin{array}{l}\text { Peserta didik aktif dalam presentasi dan bertanya apabila } \\
\text { menemukan kesulitan }\end{array}$ & 31 & 6,89 & 31 & 89,65 \\
\hline 5. & Peserta didik membaca teks ordinal number dengan baik & 31 & 51,72 & 31 & 72,41 \\
\hline \multicolumn{2}{|c|}{ Jumlah } & 98 & 3372 & 123 & 424,12 \\
\hline \multicolumn{2}{|c|}{ Rata-rata } & \multicolumn{2}{|c|}{$67,58 \%$} & \multicolumn{2}{|c|}{$84,82 \%$} \\
\hline \multicolumn{2}{|c|}{ Peningkatan (\%) } & \multicolumn{4}{|c|}{$17,24 \%$} \\
\hline
\end{tabular}

Tabel 2 menunjukkan peningkatan keaktifan peserta didik selama pembelajaran. Penggunaan bola-bola hypnotist dalam $5 M$ juga terbukti dapat meningkatkan keaktifan kelas VIIA Sekolah Menengah Pertama Negeri 1 Sarang. Selama pembelajaran pada siklus 1 dan siklus 2, kolaboran melakukan observasi. Kolaboran menggunakan lembar observasi yang telah disediakan sebelumnya, untuk mengamati pendidik, peserta didik, maupun pelaksanaan pembelajaran. Hasil observasi menunjukkan persentase keaktifan peserta didik meningkat dari siklus 1 sebesar $67,58 \%$ menjadi $84,52 \%$ pada siklus 2 . Artinya, ada peningkatan sebesar $17,24 \%$.

\section{Pembahasan}

Sebelum melakukan penelitian, penulis melakukan tes pra siklus. Penulis memberikan beberapa soal tentang ordinal number kepada kelas VIIA di Sekolah Menengah Pertama Negeri 1 Sarang. Test ini bertujuan untuk mengetahui kemampuan membaca ordinal number peserta didik. Hasil test menunjukkan kemampuan mereka sangat rendah, dengan perolehan rata-rata hanya 45,40\%. Dari peserta didik yang jumlahnya 32, tak seorang pun mampu mendapatkan nilai dengan kategori baik. Mereka 
hanya mampu mendapatkan nilai dengan kategori cukup. Itu pun persentasenya hanya 5,5\%. Sisanya, sebesar 94,5\% memperoleh nilai dengan kategori kurang.

Harusnya ini tidak terjadi, karena pada saat pembelajaran mereka terlihat antusias dan bisa mengikuti. Ditambah lagi, mereka telah memperoleh materi ordinal number ketika di Sekolah Dasar. Penulis berasumsi hasil test mereka rendah karena hasil belajar mereka tidak terekam kuat dalam memori. Ini terjadi karena penggunaan metode serta strategi pembelajaran yang kurang tepat. Akibatnya, pengetahuan yang telah mereka dapatkan mudah terlupakan. Oleh sebab itu, perlu adanya inovasi oleh guru dalam menggunakan media pembelajaran. Kaylene \& Rosone dalam Gustina menyatakan bahwa media pembelajaran akan semakin berkembang dengan pesat. Penggunaan media perlu diadakan penemuan baru yang lebih baik. Media yang digunakan harus menarik dan sesuai dengan karakteristik peserta didik sehingga dapat memotivasi untuk belajar (Dasar et al., 2021).

Untuk itulah penulis menciptakan bola-bola hypnotist ini. Secara sederhana hypnotist diartikan sebagai sebuah kondisi yang mirip tidur dimana alam bawah sadar lebih mengambil peranan dan alam sadar berkurang perananya. Pada kondisi ini seseorang akan menjadi sangat mudah diberi instruksi atau saran, (Rohdian Al-Ahad, 2017). Dari pengertian diatas diharapkan bola-bola hypnotist akan dapat mengaktifkan alam bawah peserta didik. Mereka akan lebih mudah menerima instruksi dan semakin aktif dalam pembelajaran.

Hasil test pra siklus ini penulis jadikan pijakan untuk melakukan perubahan menuju peningkatan. Penulis kemudian membuat media pembelajaran berupa bola-bola Hypnotist. Kemudian dalam pelaksanaanya, penulis kombinasikan dengan $5 \mathrm{M}$, yaitu pendekatan saintifik yang langkah-langkahnya terdiri dari Mengamati, Menanya, Mengumpulkan data, Mengasosiasi, dan Mengomunikasi.

Setelah melakukan diskusi dengan kolaboran terkait perencanaan siklus 1, penulis melakukan pembelajaran membaca ordinal number dengan bola-bola hypnotist dalam 5M. Pada siklus 1 ini penulis mengambil tema "kehidupan di sekolah". Penulis berharap tema ini akan memudahkan peserta didik dalam mengikuti pembelajaran, karena tema ini sangat 
dekat dengan kehidupan. Mereka sudah sangat mengenal kosakata yang berhubungan dengan kehidupan di sekolah. Siklus 2 penulis mengambil tema kehidupan di rumah. Tema ini pun sangat membantu peserta didik, karena tema ini juga sangat dekat dengan kehidupan mereka. Penggunaan bolabola hypnotist dalam peneitian ini dapat terbaca dari tabel 3 dan 4 berikut:

Tabel 3. Penggunaan Bola-bola Hypnotist dalam Pembeajaran Membaca Ordinal

\begin{tabular}{|c|c|c|c|c|c|}
\hline \multirow{2}{*}{$\begin{array}{l}\text { Bola-bola } \\
\text { Hypnotist }\end{array}$} & \multirow{2}{*}{$\begin{array}{l}\text { Instruksi/ } \\
\text { Pertanyaan }\end{array}$} & \multicolumn{4}{|c|}{ Penggunaan } \\
\hline & & Siklus 1 & Tema & Siklus 2 & Tema \\
\hline $\begin{array}{l}\text { Merah } \\
\text { muda }\end{array}$ & $\begin{array}{l}\text { Read loudly! (Bacalah } \\
\text { dengan eras!) }\end{array}$ & \multirow{5}{*}{$\begin{array}{l}\text { Pertemuan } \\
1 \text { dan } 2\end{array}$} & \multirow{5}{*}{$\begin{array}{l}\text { Kehidupan } \\
\text { di sekolah }\end{array}$} & \multirow{5}{*}{$\begin{array}{l}\text { Pertemuan } \\
1 \text { dan } 2\end{array}$} & \multirow{5}{*}{$\begin{array}{l}\text { Kehidupan } \\
\text { di rumah }\end{array}$} \\
\hline Kuning & $\begin{array}{l}\text { What time is it? (Jam } \\
\text { berapa?) }\end{array}$ & & & & \\
\hline Hijau & $\begin{array}{l}\text { Attention, please! (Mohon } \\
\text { perhatian!) }\end{array}$ & & & & \\
\hline Oranye & $\begin{array}{l}\text { Write the sentences! } \\
\text { (Tulislah kalimat- } \\
\text { kalimat tersebut!) }\end{array}$ & & & & \\
\hline Ungu & $\begin{array}{l}\text { Answer the questions! } \\
\text { (Jawablah pertanyaan } \\
\text { terebut) }\end{array}$ & & & & \\
\hline
\end{tabular}

Tabel 4. Bola-bola Hypnotist dalam 5M

\begin{tabular}{|c|c|c|c|c|c|}
\hline \multirow{2}{*}{$\begin{array}{l}\text { Bola-bola } \\
\text { Hypnotist }\end{array}$} & \multirow[b]{2}{*}{ Instruksi/ Pertanyaan } & \multicolumn{4}{|c|}{$5 M$} \\
\hline & & $\begin{array}{c}\text { Siklus } \\
1 \\
\end{array}$ & Langkah & Siklus 2 & langkah \\
\hline $\begin{array}{l}\text { Merah } \\
\text { muda }\end{array}$ & $\begin{array}{l}\text { Read loudly! (Bacalah } \\
\text { dengan keras!) }\end{array}$ & & $\begin{array}{l}\text { Mengama } \\
\text { ti }\end{array}$ & & Mengamati \\
\hline Kuning & $\begin{array}{l}\text { What time is it? (Pukul } \\
\text { berapa?) }\end{array}$ & $\begin{array}{l}\text { Pertem } \\
\text { uan } 1\end{array}$ & Menanya & Pertemuan 1 & Menanya \\
\hline Hijau & $\begin{array}{l}\text { Attention, please! (Mohon } \\
\text { perhatian!) }\end{array}$ & & $\begin{array}{l}\text { Mengump } \\
\text { ulkan data }\end{array}$ & & $\begin{array}{l}\text { Mengump } \\
\text { ulkan data }\end{array}$ \\
\hline Oranye & $\begin{array}{l}\text { Write the sentences! (Tulislah } \\
\text { kalimat-kalimat tersebut!) }\end{array}$ & & $\begin{array}{l}\text { Mengasos } \\
\text { iasi }\end{array}$ & & $\begin{array}{l}\text { Mengasosi } \\
\text { asi }\end{array}$ \\
\hline Ungu & $\begin{array}{l}\text { Answer the questions! } \\
\text { (Jawablah pertanyaan } \\
\text { terebut) }\end{array}$ & uan 2 & $\begin{array}{l}\text { Mengomu } \\
\text { nikasi }\end{array}$ & Pertemuan 2 & $\begin{array}{l}\text { Mengomu } \\
\text { nikasi }\end{array}$ \\
\hline
\end{tabular}

Bagaimana bola-bola hypnotist dalam 5M dapat meningkatkan kemampuan membaca ordinal number dapat dijelaskan sebagai berikut. Seperti yang penulis jelaskan bahwa bola-bola hypnotist adalah media pembelajaran, maka sebelum penggunaan media tersebut, peserta didik harus mengenal dulu apa bola-bala hypnotist itu. Apa fungsinya dalam pembelajaran, serta bagaimana cara kerja media tersebut. Ini perlu 
diinformasikan kepada peserta didik, agar dalam pelaksanaanya tidak menemui kendala. Ini harus dilakukan supaya bola-bola hypnotist dapat berfungsi secara maksimal dan tujuan penelitian dapat terwujud.

Pada pertemuan pertama siklus 1, penulis mengambil 20 menit untuk kegiatan pembukaan pembelajaran. Waktu ini lebih panjang dibandingkan dengan kegiatan pembukaan pembelajaran biasa yang hanya mengambil waktu 5 - 10 menit. Yang pertama, penulis melibatkan peserta didik untuk menempel lima bola dari bahan karet dengan warna-warna mencolok yang berbeda di papan tulis. Selanjutnya, peserta didik diminta menempelkan satu dari lima potongan kertas yang berisi instruksi/ pertanyaan yang disediakan, di bawah bola-bola tadi. Peserta didik boleh mencocokkan instruksi dengan warna apapun, sampai kelima instruksi tertempel di bawah kelima bola tadi. Keterlibatan peserta didik ini penting, sebagaimana dikemukakan Sardiman A.M dalam Wathroh Mursyidi, bahwa belajar itu akan lebih baik, kalau si subjek belajar mengalami atau melakukannya, jadi tidak bersifat verbalistik (Mursyidi, 2020).

Kelima bola tersebut adalah:1) bola dengan warna merah muda, mewakili instruksi "Read loudly!", artinya "Bacalah dengan keras!", 2 ) bola dengan warna kuning, mewakili pertanyaan"What time is it?", "pukul berapakah?", 3) bola dengan warna hijau, mewakili instruksi "Attention, please!", artinya "Mohon perhatian!", 4) bola dengan warna oranye, mewakili instruksi "Write the sentences!", artinya "Tulislah kalimat-kalimat tersebut!", dan 5) bola dengan warna ungu, mewakili instruksi "Answer the questions!", artinya "Jawablah pertanyaan-pertanyaan tersebut!".

Selain itu, penulis juga menyiapkan lima buah bola sejenis dengan warna yang sama pula. Bola-bola ini yang penulis sebut sebagai bola-bola hypnotist, yang berfungsi sebagai media pembelajaran. Bola-bola hypnotist ini akan mengecohkan dan menembus critical area dan akan menembus pikiran bawah sadar peserta didik, kemudian mengaktifkanya selama pembelajaran. Dengan dominasi pikiran bawah sadar, peserta didik akan merasa rileks dalam belajar. Peserta didik akan lebih fokus, dan mereka akan menyimpan hasil belajar dengan kuat dalam memori mereka. Terjadi diskusi dalam kegiatan ini. suasana kelas menjadi gaduh, tapi sangat 
menyenangkan. Ini adalah awal yang bagus untuk sebuah pembelajaran. Rileks, tidak menegangkan.

Selanjutnya, penulis menjelaskan bagaimana fungsi bola-bola tersebut dalam pembelajaran. Penulis kemudian mengambil satu bola berwarna hijau. Penulis mengangkat bola tersebut sambil berdiri di depan kelas dan mengarahkan bola tersebut ke peserta didik. Peserta didik semuanya tibatiba terdiam, pandangan mereka mengarah ke bola yang penulis angkat. Mereka tersenyum, kemudian perlahan pandangan mereka mengarah ke bola-bola yang tertempel di papan tulis. Mereka terdiam sambil mencocokkan warna bola yang penulis pegang dengan bola yang tertempel di papan tulis. Sesaat kemudian, pandangan mereka semakin fokus ke depan. Mereka mulai mengatur posisi duduk mereka, yang tadinya kurang rapi menjadi semakin rapi. Penulis memberi apresiasi mereka dengan memberikan acungan jempol. Bola dengan warna hijau, mewakili instruksi "Attention, please!", artinya "Mohon perhatian!". Penulis tak perlu memerintah peserta didik untuk diam. Mereka cukup memperhatikan bola hijau yang penulis tunjukkan, kemudian mereka melakukan hal sesuai instruksi bola berwarna hijau.

Sejatinya, aktivitas tadi menunjukkan bahwa peserta didik telah terhipnotist. Bola warna hijau tadi telah mengecohkan critical area dan menembus pikiran bawah sadar mereka. Sehingga, mereka dengan suka rela mencocokkan warna bola yang penulis pegang dengan warna bola yang tertempel di papan tulis. Selanjutnya mereka melakukan instruksi sesuai warna bola tadi. Ini terjadi karena mereka berada dalam kondisi yang sangat nyaman, tidak dalam tekanan.

Setelah fungsi satu bola dapat dipahami, penulis melanjutkan dengan bola-bola yang lainya. Penulis mengambil satu bola lagi, berwarna merah muda dan melakukan hal yang sama seperti bola sebelumnya. Berikutnya bola kuning, oranye, dan terakhir ungu. Penulis melakukan ini sampai peserta didik memahami fungsi dari kelima bola tersebut. Yang mengagumkan, peserta didik ternyata tidak mengalami kesulitan. Waktu 20 menit cukup untuk mengenal fungsi bola-bola hypnotist.

Memasuki kegiatan inti, penulis mulai memberikan handout tentang ordinal number. Dalam $5 M$, ini masuk pada langkah "Mengamati" 
dan "Menanya". Penulis menjelaskan sejenak apa yang sebetulnya mereka telah pelajari itu. Pada saat mereka mulai kurang fokus, penulis menunjukkan kembali bola warna hijau sambil menyapa "Hallo!". Mereka merespon dengan senyum dan kembali fokus lagi. Dalam kegiatan ini penulis dan peserta didik melakukan tanya jawab tentang apa yang belum mereka pahami. Kegiatan dilanjutkan pada langkah "Mengumpulkan data". Banyak terjdi tanya jawab dalam kegiatan ini. mereka semua aktif, dan bola-bola hypnotist tetap memegang peranan penting dalam mengarahkan mereka.

Pada pertemuan kedua siklus 1, kegiatan dilanjutkan dengan kerja kelompok. Dari 32 peserta didik penulis membagi mereka menjadi 8 kelompok. Setiap kelompok terdiri dari empat peserta didik. Dalam 5M, kegiatan ini masuk pada langkah "Mengasosiasi". Semua instruksi dalam kegiatan ini menggunakan bola-bola hypnotist. Ini sangat menguntungkan. Peserta didik merasa nyaman, karena tidak tertekan oleh instruksiinstruksi verbal. Pendidik juga tidak cape, harus mengulang-ulang instruksi. Kegiatan akhir pada siklus 1 adalah presentasi, baik ke kelompok lain, maupun di depan kelas. Ini masuk pada langkah 'mengomunikasi'. Luar biasa! Mereka mulai berani melakukan presentasi tanpa paksaan.

Terbukti bola-bola hypnotist dalam $5 M$ dapat meningkatkan kemampuan membaca ordinal number kelas VIIA Sekolah Menengah Pertama Negeri 1 Sarang. Test pada akhir siklus 1 menunjukkan peningkatan nilai sebesar $34,60 \%$ dari pra siklus ke siklus 1 , dari rata-rata 45,40 meningkat menjadi 80.00. Dari hasil ini, penulis melakukan refleksi dan diskusi dengan kolaboran. Untuk lebih memantapkan hasil penelitian, penulis dan kolaboran melakukan perencanaan ulang untuk siklus 2 .

Pada siklus 2, penulis mengambil tema "kehidupan di rumah". Lagi-lagi bola-bola hypnotist dalam 5M mampu meningkatkan kemampuan membaca ordinal number kelas VIIA Sekolah Menengah Pertama Negeri 1 Sarang. Test pada akhir siklus 2 menunjukkan peningkatan nilai sebesar $3,75 \%$ dari siklus 1 ke siklus 2, dari rata-rata 80.00 meningkat menjadi 83,75 . Hasil akhir penelitian dapat terbaca dari diagram di bawah ini.

Sebagaimana rencana awal, tujuan penelitian ini juga untuk meningkatkan keaktifan peserta didik dalam mengikuti pembelajaran. Maka, pada akhir 
penelitian harus menunjukkan bahwa keaktifan peserta didik telah meningkat. Terbukti, bahwa keatifan peserta didik telah meningkat, ditandai dengan lebih fokusnya mereka selama pembelajaran. Selain itu mereka juga lebih aktif dalam kelompok. Berani melakukan presentasi. Yang lebih penting lagi mereka aktif dalam diskusi. Peningkatan tersebut dapat terbaca dari tabel di atas.

Data tentang keaktifan peserta didik ini di peroleh dari hasil observasi selama tindakan, baik tindakan pada siklus 1 maupun pada siklus 2 . Observasi ini dilakukan oleh kolaboran. Pengamatan diarahkan pada perilaku positif dan negatif peserta didik selama pembelajaran. Dua perilaku tersebut tertera dalam lembar observasi. Lembar observasi ini berisi daftar nama peserta didik kelas 7A Sekolah Menengah Pertama Negeri 1 Sarang disertai lima indikator perilaku untuk perilaku positif, dan lima indikator untuk perilaku negatif. Dalam observasi tersebut, observer yang juga kolaboran memberikan check list pada tiap indikator sesuai temuan selama observasi.

Untuk indikator perilaku positif, terdiri dari: 1) Peserta didik memperhatikan dan merespon dengan antusias (bertanya, menanggapi, dan mencatat), 2) Peserta didik berpartisipasiaktif dalam berkelompok, 3) Peserta didik merasa senang belajar teks ordinal number menggunakan media realia, 4) Peserta didik aktif dalam presentasi dan bertanya apabila menemukan kesulitan, dan 5) Peserta didik membaca teks ordinal number dengan baik. Sedangkan indikator perilaku negative terdiri dari: 1) peserta didik tidak mendengarkan penjelasan pendidik, 2) peserta didik kurang berpartisipasi dalam kelompok, 3) peserta didik acuh terhadap bola-bola hypnotis yang digunakan dalam pembelajaran, 4) peserta didik pasif dan malas bertanya apabila menemui kesulitan, dan 5) peserta didik melakukan kegiatan yang tidak perlu pada saat mengerjakan tugas-tugas membaca ordinal number mencontek, tiduran, bercanda, dsb.

Dari hasil observasi pada siklus pertama, persentase keaktifan peserta didik mencapai $67,58 \%$. Hasil obeservasi ini kemudian penulis gunakan sebagai bahan refleksi dan diskusi dengan kolaboran. Penulis juga menjadikanya sbagai acuan perbaikan perencanaan untuk siklus 2. Hasil observasi siklus 
2 menunjukkan bahwa keaktifan peserta didik meningkat menjadi 84,82\%. Artinya ada peningkatan keaktifan peserta didik sebesar 17,24\%.

Peningkatan keaktifan peserta didik ini juga terlihat dari kinerja peserta didik dalam kelompok. Mereka semakin aktif dan membantu temannya dalam kelompok serta berani mempresentasikan hasil diskusi di kelompok lain maupun di depan kelas. Keaktifan peserta didik dalam kelompok terlihat dari hubungan dan kerjasama peserta didik dalam kelompok kerjanya. Ini penulis peroleh dari lembar sosiometri yang telah diisi peserta didik. Dalam lembar sosiometri tersebut ada 4 pertanyaan yang harus dijawab peserta didik. Akan tetapi, peserta didik diperbolehkan tidak menjawab, karena alasan yang kuat. Keempat pertanyaan tersebut adalah: 1) Siapakah 1 teman dalam kelompokmu yang paling aktif?, 2) Siapakah 1 teman dalam kelompokmu yang paling tidak aktif?, 3) Siapakah 1 teman dalam kelompokmu yang sering membantumu?, dan 4) Siapakah 1 teman dalam kelompokmu yang paling susah diajak bekerja sama? Dari hasil sosiometri, kemudian dibuat sosiogram.

\section{Penutup}

Penulis menyimpulkan bahwa penelitian ini telah berhasil. Sesuai indikator yang telah ditetapkan, persentase nilai membaca ordinal number peserta didik VIIA Sekolah Menengah Pertama Negeri 1 Sarang, pada akhir penelitian mencapai $83,75 \%$, melebihi indikator yang ditetapkan, yaitu $75 \%$. Persentase ketuntasan belajar meningkat secara drastis, menjadi 90,63\%, melebihi dari indikator yang ditetapkan, yaitu 75\%. Ini menunjukkan bahwa penggunaan bola-bola hypnotist dalam $5 M$ mampu meningkatkan kemampuan membaca ordinal number. Bola-bola hypnotist dalam $5 M$ juga mampu meningkatkan keaktifan peserta didik. Data hasil penelitian menunjukkan keaktifan peserta didik dalam pembelajaran mencapai $84,82 \%$, melebihi indikator yang ditetapkan, yaitu $75 \%$. Ini semua terjadi karena Bola-bola hypnotist dalam 5M mampu mengaktifkan pikiran bawah sadar mereka. Peserta didik merasa rileks, namun lebih sugestif dalam belajar. Efeknya, hasil belajar dapat terekam secara kuat dalam memori mereka. Mereka tidak akan mudah melupakan apa yang mereka pelajari, dan mereka 
akan mudah menjawab soal-soal yang diberikan kapan saja. Semoga hasil penelitian ini bisa memacu kreativitas dan menjadi inspirasi dalam melaksanakan pembelajaran membaca ordinal number, sehingga peserta didik dapat menguasai materi ini dengan mudah dan tidak mudah melupakanya lagi. Penulis juga berharap hasil penelitian ini akan memunculkan ide-ide baru untuk melakukan Penelitian Tindakan Kelas.

\section{Ucapan Terimakasih}

Terima kasih penulis ucapkan kepada semua pihak yang telah membantu terlaksananya penelitinan ini. Khususnya, kepada Bapak Sunarso, S.Pd., kepala Sekolah Menengah Pertama Negeri 1 Sarang. Ibu Retno Endah K., S.Pd. dan Bapak Masykur Faruq, S.Pd. selaku kolaboran, yang telah memotivasi dan memberikan bantuan yang tak terhingga. Peserta didik kelas VIIA Sekolah Menengah Pertama Negeri 1 Sarang, atas peran aktifnya dalam pelaksanaan penelitian ini. Terima kasih juga kepada seluruh peserta didik Sekolah Menengah Pertama Negeri 1 Sarang yang telah banyak memberi inspirasi.

\section{Daftar Referensi}

Al-Ahad, Rohdian. (2017). Kitab Rahasia Seni Hypnoteaching. Cirebon: LovRinz Publishing

Astutik, P. P. (2018). ... Media Sampah Untuk Meningkatkan Kemampuan Literasi Dan Keterampilan Berpikir Kreatif Siswa Sekolah Dasar. Jurnal Didaktika Pendidikan Dasar, 2(2), 415-432.

Dasar, S., Payakumbuh, N., \& Barat, S. (2021). Pengembangan Media Pembelajaran Permainan Menstimulasi Pembelajaran Hots Gustina Abstrak A . Pendahuluan Ditemukan dalam kurun 20 tahun terakhir ini terjadi pergeseran pembangunan pendidikan ke arah Information and Communication Technology (ICT ), yang l. 5(1), 31-46. https://doi.org/10.26811/didaktika.v5i1.269

Dj, M. Z. (2015). Muhammad Zuhri Dj. 15(2), 185-199.

Fitriana, R. (2020). Kemampuan Intrprestasi Makna Dalam Teks Bacaan Bahasa Inggris Mahasiswa Politeknik Negeri Samarinda. Sebatik, 24(1), 45-50. https:/ / doi.org/10.46984/sebatik.v24i1.922 
Handayani, T., Nada, G., Angka, N., \& Handayani, T. (2018). Implementasi Media Grafik Nada Dengan Kendali Remote Control Untuk Meningkatkan Keterampilan di SD. 2(2), 107-118. https:/ / bit.ly/2nGPjYX

Hidayat, R. W. (2020). Peningkatan Motivasi dan Hasil Belajar Peserta Didik pada Pembelajaran Comparison Degrees melalui Lingkar Tiga Warna. Jurnal Didaktika Pendidikan Dasar, 4(1), 255-270. https://doi.org/10.26811/didaktika.v4i1.155

Husen, S., \& Mansor, R. (2018). Parents Involvement in Improving Character of Children Through Mathematics Learning. Jurnal Ilmiah Peuradeun, 6(1), 41-50. doi:10.26811/ peuradeun.v6i1.178

Jaya, U. P., Kerja, L., \& Didik, P. (2019). Media Break And Put Untuk Meningkatkan Hasil Belajar Materi Report Text Imzinaryani 1 1. 3(1), 127-144.

Jusnita, N., \& Ismail, A. (2018). Implementasi Kurikulum 2013 Dalam Pembelajaran Bahasa Inggris Di Smp Kota Ternate. Edukasi, 16(1), 1-10. https:// doi.org/10.33387/j.edu.v16i1.616

Kemdikbud RI. (2018). Permendikbud RI Nomor 37 tahun 2018 tentang Perubahan atas Peraturan Menteri Pendidikan dan Kebudayaan Nomor 24 tahun 2016 tentang Kompetensi Inti dan Kompetensi Dasar Pelajaran pada Kurikulum 2013 pada Pendidikan Dasar dan Pendidikan Menengah. JDIH Kemendikbud, 2025, 1-527.

Kemendikbud. (2014). Permendikbud Nomor 103 Tahun 2014 Tentang Pembelajaran Pada Pendidikan Dasar dan Pendidikan Menengah. Pedoman Evaluasi Kurikulum. http://pgsd.uad.ac.id/wpcontent/uploads/lampiran-permendikbud-no-104-tahun-2014.pdf

Kementerian Pendidikan dan Kebudayaan. (2017). Modul Pendidik Pembelajar Mata Pelajaran Bahasa Inggris Sekolah Menengah Pertama Kelompok Kompetensi I. Jakarta: Direktorat Jenderal Pendidik dan Tenaga Kependidikan

Kementerian Pendidikan dan Kebudayaan, 2016.Modul Pendidik Pembelajar Mata Pelajaran Bahasa Inggris Sekolah Menengah Pertama Kelompok Kompetensi I. Jakarta: Direktorat Jenderal Pendidik dan Tenaga Kependidikan

Maiti, \& Bidinger. (1981). 済無No Title No Title. Journal of Chemical Information and Modeling, 53(9), 1689-1699.

Mursyidi, W. (2020). Kajian Teori Belajar Behaviorisme Dan Desain Instruksional. Almarhalah | Jurnal Pendidikan Islam, 3(1), 33-38. https://doi.org/10.38153/alm.v3i1.30 
Noer, M. (2010). Hypnoteaching for success learning. Yogyakarta: Pedagogia, 17, 15.

Nur, L. (2017). Di Kober Al-Hidayah Kecamatan Cikoneng. 1(1), 106-117.

Nurli, ., Mursid, R., \& Tanjung, S. (2019). Pengaruh Strategi Pembelajaran Dan Motivasi Belajar Terhadap Hasil Belajar Membaca Bahasa Inggris. Jurnal Teknologi Pendidikan (JTP), 11(2), 195. https://doi.org/10.24114/jtp.v11i2.12585

Pane, D. N., Fikri, M. EL, \& Ritonga, H. M. (2018). Creating Effective Learning Through Hypnoteaching. Journal of Chemical Information and Modeling, 53(9), 1689-1699.

Pertiwi, SPd., Hana,. 2014. Hypnoteaching untuk PAUD dan TK. Jogjakarta: DIVA Press

Sachmadi, I. F., Manggong, L., \& Indrayani, L. M. (2018). Sikap Bahasa Dan Kemampuan Memahami Bacaan Bahasa Inggris Mahasiswa: Studi Kasus Di Fib Unpad. Sosiohumaniora, 21(1), 98. https://doi.org/10.24198/sosiohumaniora.v21i1.14541

Sari, T. T., \& Hanip, R. (2018). Pendekatan Scientifik Dalam Penerapan Kkni Pada Pembelajaran Ips Sd. Alpen: Jurnal Pendidikan Dasar, 1(1), 32-38. https:// doi.org/10.24929/alpen.v1i1.5

Saubas, H. U. (2016). Implementasi Kurikulum 2013 Melalui Penerapan Pendekatan Saintifik Dalam Pembelajaran Bahasa Indonesia Berbasis Teks Di Sekolah Menengah Pertama (Smp). Edukasi, 13(1), 208-215. https://doi.org/10.33387/j.edu.v13i1.30

Sri Wahyuni. (2015). Pengaruh Bahasa Pertama Terhadap Bahasa Kedua Dalam Kemampuan Berbicara Untuk Siswa Kelas Ix Pesantren Modern Al-Falah Abu Lam-U Kabupaten Aceh Besar. Visipena Journal, 6(2), 52-67. https://doi.org/10.46244/visipena.v6i2.365

Susanto, H. (2020). Reading Theories and Reading Comprehension; Review and Discussed. E-Structural, 2(2), 153-159. https://doi.org/10.33633/es.v2i2.3231

Tabrani ZA. (2014). Dasar-Dasar Metodologi Penelitian Kualitatif. Yogyakarta: Darussalam Publishing.

Vinet, L., \& Zhedanov, A. (2011). A “missing" family of classical orthogonal polynomials. Journal of Physics A: Mathematical and Theoretical, 44(8), 1689-1699. https://doi.org/10.1088/1751-8113/44/8/085201 